\title{
Chapter 7 \\ Engaging with Gender in Water Governance and Practice in Kenya
}

\author{
Chinwe Ifejika Speranza and Edward Bikketi
}

\begin{abstract}
How water is distributed, who has access and can make decisions on its use depends on various social, structural and institutional factors, among them gender. This paper examines the extent to which water-related policies and plans of the Kenyan government engage with gender. It analyses how the framing conditions set by the policies and plans affect the management of community water groups in Laikipia, and assesses whether the community water groups through their activities reduce gender inequality in access to water and in decision making about water-use. It uses a gender analytical framework that identifies three levels of engagement, whereby engagement occurs in a continuum: (1) gender mainstreaming, (2) the experience of gender in terms of addressing practical and strategic gender needs, and (3) the degrees of action to reduce gender inequality. We find that the Kenyan public policy has institutionalised various measures to reduce gender inequality, a major strategy being to limit the representation of either men or women to twothirds in any governance arrangement. This means a $30 \%$ minimum representation of women. This top-down structural measure has permeated government ministries, departments and agencies and has become a precondition for government practice and interventions, including the water sector. By being an obligation, it is transformative in that it changes the way governance has been conducted prior to the policy change and serves as a benchmark for practice within and outside government. Bound by the water governance arrangements of the government, most community water groups have had to adopt the "two-thirds gender rule". This policy measure has thus trickled down to local water governance. However, achieving strategic gender goals remains a challenge, highlighting how gender mainstreaming is inadequate to completely reduce gender inequality. Additional efforts are needed to change socio-cultural beliefs and norms to support a more gender-equitable access to water. Furthermore, an analysis of the community water groups highlight that
\end{abstract}

C. Ifejika Speranza $(\triangle)$

Institute of Geography, University of Bern, Bern, Switzerland

e-mail: chinwe.ifejika.speranza@ giub.unibe.ch

E. Bikketi

International Crops Research Institute for the Semi-Arid Tropics (ICRISAT-Nairobi),

Nairobi, Kenya

e-mail: e.bikketi@cgiar.org

C. Fröhlich et al. (eds.), Water Security Across the Gender Divide,

Water Security in a New World, DOI 10.1007/978-3-319-64046-4_7 
financial capability may be a stronger factor than gender in determining men and women's access to water in Laikipia, Kenya. Thus in addition to addressing sociocultural beliefs and norms, there is a need to explore the intersections of gender and capabilities, and the roles they play in reducing gender inequality in water use and governance.

Keywords Water governance - Kenya • Community water groups • Inequality • Gender mainstreaming

\subsection{Introduction}

Disparities in water availability and access are major development concerns. How water is distributed, who has access and can make decisions on its use depends on various institutional, structural and social factors, among them gender. ${ }^{1}$ Gender affects the distribution of resources and responsibilities and remains one of the most widespread categories of social inequality, with enormous local and cultural variations (Boserup 1970; Tinker 1990; Elson 1995; Ifejika Speranza 2006; Wyrod 2008). Ridgeway and Correll $(2004,511)$ argue that "widely shared, hegemonic cultural $^{2}$ beliefs about gender and their effects in "social relational contexts" (situations in which individuals define themselves in relation to others in order to act) are among the core components" that make a gender system persist or open to change. Gender ideology and beliefs that are hegemonic are institutionalized in various spheres of society such as in the media, government policy, normative images of the family (Ridgeway and Correll 2004) and markets. Gender is both socially determined and performative and can change through both individual and social action (Butler 1990). Quisumbing (1996, 1580) thus argues that since gender is socially determined, it can be changed through conscious social action including public policy (op. cit).

Yet, policy formulation, planning and implementation in the water and related agricultural sectors continue to exclude or misinterpret women's needs, interest and experiences and/or subsume them with those of men (Kabeer 2010; Elson 1995). Policies may contradict one another in their engagement with gender (Rao 2017),

\footnotetext{
${ }^{1}$ Drawing on literature, Ridgeway and Correll $(2004,510)$ refer to gender as "an institutionalised system of social practices for constituting people as two significantly different categories of men and women, and organising social relations of inequality on the basis of that difference". A gender system "... involves cultural beliefs and distribution of resources at the macro level, patterns of behaviour and organisational practices at the interactional level, and selves and identities at the individual level" (p. 501-502).

${ }^{2}$ Gramsci's concept of cultural hegemony addresses the relation between culture and power under capitalism (Jackson Lears 1985, 568), and "refers to a historical process in which a dominant group exercises 'moral and intellectual leadership' throughout society by winning the voluntary 'consent' of popular masses" (Kim 2001, 742).
} 
may have destructive impacts on rural-based livelihoods (Bryceson 1999), but can also lead to cracks in a gender ideological order (Bryceson 1999). However, whether policies and their implementation reduce or increase gender discriminations depends on the social structures and relations and the pre-existing gender discriminations in specific contexts (Bryceson 1999; Daley 2011; Rao 2017).

Although the roles of women in the water and agriculture sector vary widely across the developing world, women farmers share a common set of gender-based disadvantages (Bikketi et al. 2016; Farnworth et al. 2013; Ifejika Speranza 2006). They tend to have less access than men to productive resources like water, land, livestock, and labour, less access to credit, limited control over household income, less access than men to agriculture inputs, extension services and markets (Bikketi et al. 2016; Ifejika Speranza 2006; Mackenzie 1990). In Sub-Saharan Africa (SSA), where about $80 \%$ of women depend on agriculture for their livelihoods (SOFA and Doss 2011), deeply rooted gender discrimination contributes significantly to low productivity and profitability of women's economic enterprises, which in turn exacerbate poverty, food insecurity and malnutrition. A gender analysis thus illuminates evolving differences in the needs, priorities, roles, statuses, and capacities of men and women, as well as the constraints and opportunities they face (Doss and Kieran 2015).

Furthermore, a majority of women smallholders in SSA have very low literacy levels, few marketable skills, and little access to formal or informal income generating activities (FAO 2011). In patriarchal communities, these women generally have no right to inherit land, a crucial livelihood asset, leaving them wholly dependent on their husbands and/or male relatives for their financial security and wellbeing despite explicit provisions by various Constitutions (Ifejika Speranza 2006; Doss et al. 2012; Lastarria-Cornhiel et al. 2014; Bikketi et al. 2016). The male household heads typically decide what to do with household resources, leading to insecure access to resources required for sustained agricultural production (Ifejika Speranza 2006; Wyrod 2008; WDR-World Development Report 2012, 72-91; Kassie et al. 2014; Dancer and Tsikata 2015). Thus the rights of women to access and control resources such as land or water remain a matter of concern.

In SSA, water as a resource has layered rights based on use, control and ownership. These rights extend from (i) access (physically accessing the resource), (ii) extraction (ability to take a part of the resource) (iii) management rights or decisionmaking about the resource, (iv) exclusion rights, and (v) rights of alienation (decision-making about sale, lease or bequeathing the resource) (Rao 2016 citing Schlager and Ostrom 1992). These rights affect men and women differently (Daley 2011; Tsikata and Yaro 2014). For example, fetching water for domestic use is a responsibility that is normally assigned to women and children in various sociocultural contexts (Ifejika Speranza 2006; Gallois et al. 2015). Such is the case in many regions of Kenya, a country that is considered water-scarce with less than $1000 \mathrm{~m}^{3}$ of renewable fresh water supplies per capita and year (USAID 2014).

Thus where water supply is difficult, e.g. in many rural areas, women and children have to put in extra time and labour to access enough quantity of water that is of good quality for household needs. Being responsible for household management, women have an interest in secure water supply. Thus among addressing other devel- 
opment challenges, women in various rural areas of Kenya have organised themselves into groups to improve their access to water, for instance, by contributing money to purchase water tanks for each member (Mutugi 2006).

However there are cases where water supply and access becomes a broader challenge affecting both men and women's lives. In such cases both men and women self-organise to improve their access to water for various uses. This is the case of the Community Water Groups (CWGs), that is, self-help groups that aim to improve their members' access to water, in the upper Ewaso-Ngiro river basin in the Mount Kenya region. Such a case raises questions on (i) whether gender inequalities persist in water access and use (ii) what measures CWGs put in place to reduce gender inequality in water resources management, and (iii) to what extent the policies and practices of the various relevant government bodies foster the capacity of men and women to access water. This paper thus has three objectives: First, to examine the extent to which water-related policies and plans of the Kenyan government engage with gender. Second, to analyse how the framing conditions set by the policies and plans affect the management of CWGs. And third, to explore whether the CWGs through their activities reduce gender inequality in access to water and in decision making about water-use. Such a focus can provide insights on the effectiveness of top-down structural measures (as reflected by government plans, policies and practices) and bottom-up measures as reflected in the self-organisation of CWGs in reducing gender inequality in water access and use. The paper is thus structured as follows, first we present the methodological and conceptual framework, we examine how the policies and plans engage with gender, then we analyse how participation in CWGs reduce gender inequality in decisions on water use and management and whether the benefits are equitable in gender terms. Lastly, we discuss the implications of our findings and conclude.

\subsection{Methodology}

We adopted a two-pronged approach. First, we analysed policy documents including bills and acts as well as other strategic plans and annual reports of relevant government bodies, where available. And second, we collected empirical data from a survey and key informant interviews of CWGs in the Upper Ewaso-Ngiro North basin of Kenya to examine how gender mediates access to water and how gender is accounted for in local water management.

\subsubsection{Conceptual Framework}

We modified the assessment framework of gender engagement proposed by Bunce and Ford (2015) into a conceptual framework of policy engagement with gender (see Table 7.1). The authors identified three levels of gender engagement, whereby 
Table 7.1 Gender Engagement Framework - examining the level to which government policies and plans are engaging with gender

\begin{tabular}{|c|c|c|}
\hline $\begin{array}{l}\text { Attributes and dimensions of } \\
\text { engagement }\end{array}$ & Questions/indicators & $\begin{array}{l}\text { Scoring system } \\
\text { (Yes: } 1 ; \text { No:0) }\end{array}$ \\
\hline \multicolumn{2}{|c|}{$\begin{array}{l}\text { 1. Gender mainstreaming: extent to which gender concepts are being } \\
\text { applied in the policy process }\end{array}$} & Total possible score: 3 \\
\hline \multirow[t]{4}{*}{ (i) Gender-sensitivity } & $\begin{array}{l}\text { "Is there explicit recognition of the } \\
\text { different needs and experiences by } \\
\text { gender"a? }\end{array}$ & \multirow{3}{*}{ 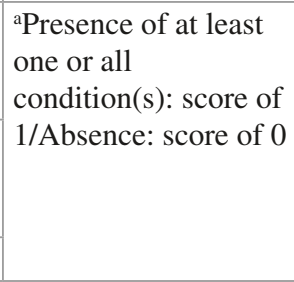 } \\
\hline & $\begin{array}{l}\text { "Are there objectives, actions, and/or } \\
\text { indicators that aim to reduce gender } \\
\text { disparities"a? }\end{array}$ & \\
\hline & "Is gender sensitive language used"a? & \\
\hline & & Total Score: 1 \\
\hline \multirow[t]{4}{*}{ (ii) Gender-responsiveness } & $\begin{array}{l}\text { "Is the Information presented in a } \\
\text { gender-disaggregated manner"a? }\end{array}$ & \multirow{3}{*}{$\begin{array}{l}\text { Presence of at least } \\
\text { one or all } \\
\text { condition(s): score of } \\
\text { 1/Absence: score of } 0\end{array}$} \\
\hline & $\begin{array}{l}\text { "Do progress indicators measure or plan } \\
\text { to measure the different impacts } \\
\text { experienced by each gender"a? }\end{array}$ & \\
\hline & $\begin{array}{l}\text { "Are there recommendations or evidence } \\
\text { of equal participation in decision- } \\
\text { making processes by all genders"a? }\end{array}$ & \\
\hline & & Total Score: 1 \\
\hline \multirow[t]{4}{*}{$\begin{array}{l}\text { (iii) Gender- } \\
\text { transformativeness }\end{array}$} & $\begin{array}{l}\text { Does the policy propose/plan activities } \\
\text { that can trigger changes in social } \\
\text { values? }\end{array}$ & \multirow{3}{*}{$\begin{array}{l}\text { Presence of at least } \\
\text { one or all } \\
\text { condition(s): score of } \\
\text { 1/Absence: score of } 0\end{array}$} \\
\hline & $\begin{array}{l}\text { Does the policy promote the rethinking } \\
\text { of societal structures of power as they } \\
\text { relate to gender? }\end{array}$ & \\
\hline & $\begin{array}{l}\text { Does the policy propose/plan changes in } \\
\text { organisational practices and goals? }\end{array}$ & \\
\hline & & Total Score: 1 \\
\hline \multicolumn{2}{|c|}{$\begin{array}{l}\text { 2. Experience of gender: extent to which the specific needs of different } \\
\text { genders are acknowledged and addressed in the policy/plan. }\end{array}$} & Total possible score: 3 \\
\hline (iv) Practical needs & $\begin{array}{l}\text { Does the policy/plan focus on } \\
\text { improving the practical and } \\
\text { differentiated needs each gender } \\
\text { experiences within current gender } \\
\text { norms? }\end{array}$ & $\begin{array}{l}\text { Presence: score of } 1 / \\
\text { Absence: score of } 0\end{array}$ \\
\hline \multirow[t]{2}{*}{ (v) Strategic needs } & $\begin{array}{l}\text { Does the policy/plan aim to reduce } \\
\text { gender inequality through a } \\
\text { re-evaluation of power distribution/ } \\
\text { societal roles and responsibilities/legal } \\
\text { rights? }\end{array}$ & $\begin{array}{l}\text { Presence: score of } 2 / \\
\text { Absence: score of } 0\end{array}$ \\
\hline & & Total Score 3 \\
\hline \multicolumn{2}{|c|}{$\begin{array}{l}\text { 3. Degree of action: extent of action being taken to reduce gender } \\
\text { inequality in the policy/plan }\end{array}$} & Total possible score: 3 \\
\hline
\end{tabular}


Table 7.1 (continued)

\begin{tabular}{|c|c|c|}
\hline $\begin{array}{l}\text { Attributes and dimensions of } \\
\text { engagement }\end{array}$ & Questions/indicators & $\begin{array}{l}\text { Scoring system } \\
\text { (Yes:1; No:0) }\end{array}$ \\
\hline $\begin{array}{l}\text { (vi) Statements of } \\
\text { recognition }\end{array}$ & $\begin{array}{l}\text { Does the policy/plan acknowledge that } \\
\text { a relationship exists between gender } \\
\text { and water? }\end{array}$ & $\begin{array}{l}\text { Presence: score of } 1 / \\
\text { Absence: score of } 0\end{array}$ \\
\hline \multirow[t]{2}{*}{ (vii) Groundwork } & $\begin{array}{l}\text { Are recommendations made that would } \\
\text { reduce gender inequality in water use } \\
\text { and governance? }\end{array}$ & \multirow{2}{*}{$\begin{array}{l}\text { Presence of at least } \\
\text { one or all } \\
\text { condition(s): score of } \\
\text { 1/Absence: score of } 0\end{array}$} \\
\hline & $\begin{array}{l}\text { Are recommendations made that aim to } \\
\text { reduce gender inequality through water } \\
\text { management and governance processes? }\end{array}$ & \\
\hline (viii) Concrete Action & $\begin{array}{l}\text { Does the policy/plan describe concrete } \\
\text { actions that have been taken or are } \\
\text { being taken to reduce gender } \\
\text { inequality in water use and } \\
\text { governance? }\end{array}$ & $\begin{array}{l}\text { Presence: score of } 1 / \\
\text { Absence: score of } 0\end{array}$ \\
\hline
\end{tabular}

Adapted from Bunce and Ford $(2015,4)$

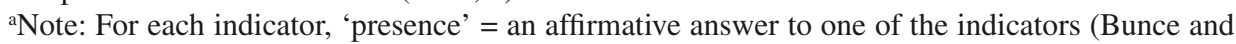
Ford 2015, 4)

engagement occurs in a continuum: (1) gender mainstreaming, (2) the experience of gender in terms of addressing practical and strategic gender needs, and (3) the degrees of action to reduce gender inequality. These three levels, which we refer to as dimensions are further divided into eight sub-dimensions (Table 7.1).

In the model of engagement proposed by Bunce and Ford (2015), gender mainstreaming refers to the process/strategy whereby gender equity and equality issues are addressed across all governmental policy spheres, rather than in small, marginalised policy units devoted exclusively to women's issues (Alston 2009; UN 1997). The authors conceptualise gender mainstreaming as a function of (i) gendersensitivity, (ii) gender-responsiveness and (iii) gender transformativeness, whereby gender-sensitivity refers to the acknowledgment of different gender experiences and needs, and the use of gender-sensitive language. Gender-responsiveness refers to presenting data and other issues in a gender-disaggregated manner, while gendertransformativeness captures the re-evaluation of current norms, values and practices to include gender (Bunce and Ford 2015, op. cit).

According the authors, policies and strategic plans that engage with gender at a low level simply acknowledge that gender exists (gender awareness) and in some way interacts with the issues being addressed (Bunce and Ford 2015). In contrast, policies and plans that engage with gender at a higher level acknowledge different gender experiences in terms of (iv) practical and (v) strategic gender needs. Such policies and strategies consider gender throughout an intervention, recognise and highlight the underlying power structures and deeply entrenched inequalities in power between socioeconomic classes and between women and men.

The degrees of action to reduce gender inequality can be in the form of (vi) "statements of recognition" acknowledging that a relationship exists between an 
issue and gender; (vii) "groundwork statements" that recommend reductions in gender inequality and proposing (viii) "concrete actions" to reduce gender inequality (Table 7.1).

We developed an assessment framework to operationalise the conceptual model and assess the levels of engagement with gender in policies and strategic plans by government as a whole (e.g. Constitution) and in its various bodies in water and related sectors (agriculture, land, and climate information). While policies and plans may not mirror actual implementation, they still capture government intentions to implement measures. Key policies in the water and agriculture sectors including guidelines, regulations and strategic plans were identified by reviewing a government list of policies and websites of the ministries and government bodies responsible for gender, water and agriculture. These were then scored according to their engagement with gender whereby those documents that did not address gender in any form were scored zero. The higher the score for each policy/plan, the higher its engagement with gender in the three dimensions described in Table 7.1. As policies do not feature "groundwork" and "concrete action" (Table 7.1), we also reviewed additional lower level documents (e.g. programmes and project reports as well as annual reports) to capture government practice and to complement the basis for scoring performance in "groundwork" and "concrete action". The scores were then summed to capture the level of engagement with gender. Following Bunce and Ford (2015), an engagement index was calculated in a table by summing scores for the dimensions indices "using equal weighting on a nine point scale" (note that "strategic needs" has a maximum value of 2). Based on this scale, policies and plans were then categorized as having high (scores of 7-9), moderate (scores of 4-6), or low levels (scores of 0-3) of engagement with gender (Bunce and Ford 2015).

\subsubsection{Analysis of Policy Documents, Plans and Other Government Reports}

To investigate ways in which Kenyan government organisations engage with gender in their policies, strategic plans and practices, we first identified government bodies that have mandates for water resources management or mandates related to land and environment. We screened 34 documents of the government of Kenya and narrowed down to 19 policy documents for in-depth analysis. Besides policies, we also analysed annual reports of line ministries where available. The documents were uploaded in MAXQDA®, a software for qualitative data analysis and coded using the 8 subdimensions in Table 7.1. In parallel, the scores were entered into a table and summed, to reflect the level of engagement with gender in the policies and plans - the higher the total score, the higher the engagement of policies and plans with gender. 


\subsubsection{Empirical Data Collection and Analysis}

To capture the reality on the ground we analysed empirical data collected in 20112012 from respondents in 30 water development interventions in the Upper EwasoNgiro North basin of Kenya to examine how gender mediates access to water and how gender is considered in local water management. The data collection was in the context of a research project on the impacts of development interventions in the Laikipia region, where a gender dimension in water management was one of the aspects captured. The data were collected through surveys targeting 290 households out of the 6808 members of the CWGs and key informant interviews of the members of the management committee of the $30 \mathrm{CWGs}$. The respondents from the household survey comprised $40 \%$ male household heads, $20 \%$ female household heads, $38 \%$ wives and $1 \%$ each of an adult son and daughter (see Ifejika Speranza et al. 2016). This empirical data on gender and local practices of water resources management enriches the policy analysis and assessment. Descriptive statistics were used to examine gender engagement by the CWGs.

\subsection{Results}

We structure the results into two main parts: (i) public sector engagement with gender and water and (ii) the practice of engaging with gender in community water projects.

\subsubsection{Public Sector Engagement with Gender in Water and Water-Related Sectors}

The results of the analysis of 19 policy documents and plans on the water-and waterrelated sectors are presented in Figs. 7.1 and 7.2 according to the sector and where possible in chronological order. Figure 7.1 provides a detailed view (according to the 8 sub-dimensions) of the level of engagement with gender by the policies and plans while Fig. 7.2 summarises them into the three dimensions of gender engagement. Out of the 19 policies and plans 6 policies scored high (7-9 points) in their engagement with gender, 8 scored moderate (4-6 points) while 5 scored low (0-3) in engagement with gender (Fig. 7.2; see also Annex 7.1).

In the following, drawing on the results presented in Figs. 7.1 and 7.2 and literature review, we structure the results of the policy and document analysis into four sections, namely, (1) the general gender policy framework in Kenya, (2) Engaging with gender in the water sector, (3) Engaging with gender in other water-related sectors, (4) Engaging with gender in climate policy and, (4) Levels of engaging the different sub-dimensions of gender. 


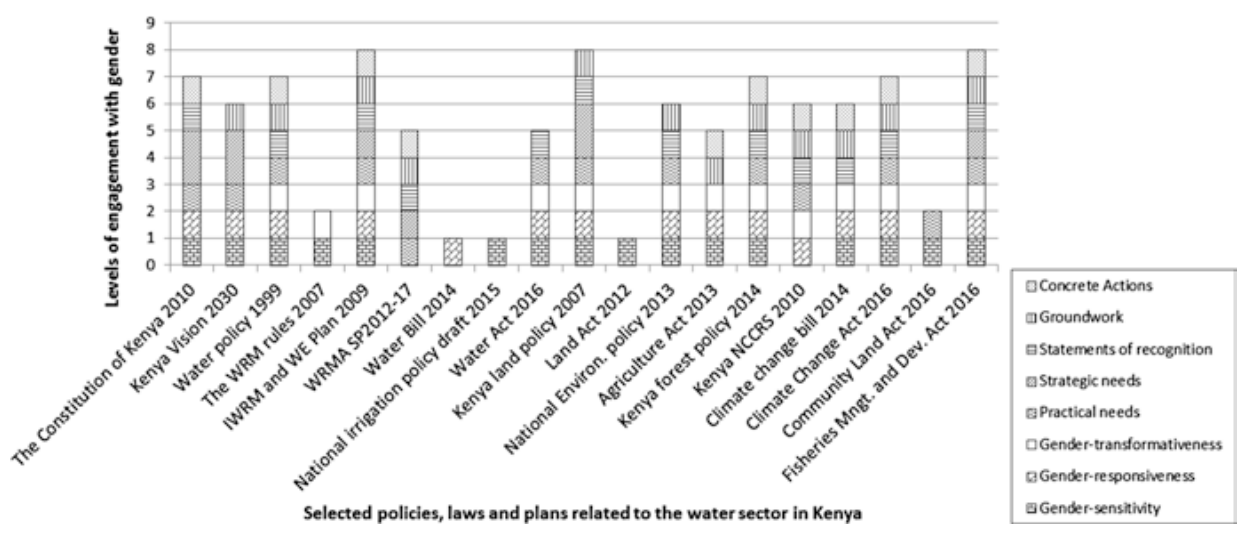

Fig. 7.1 Levels of engagement with gender equality in eight sub-dimensions in water- and related policies and plans

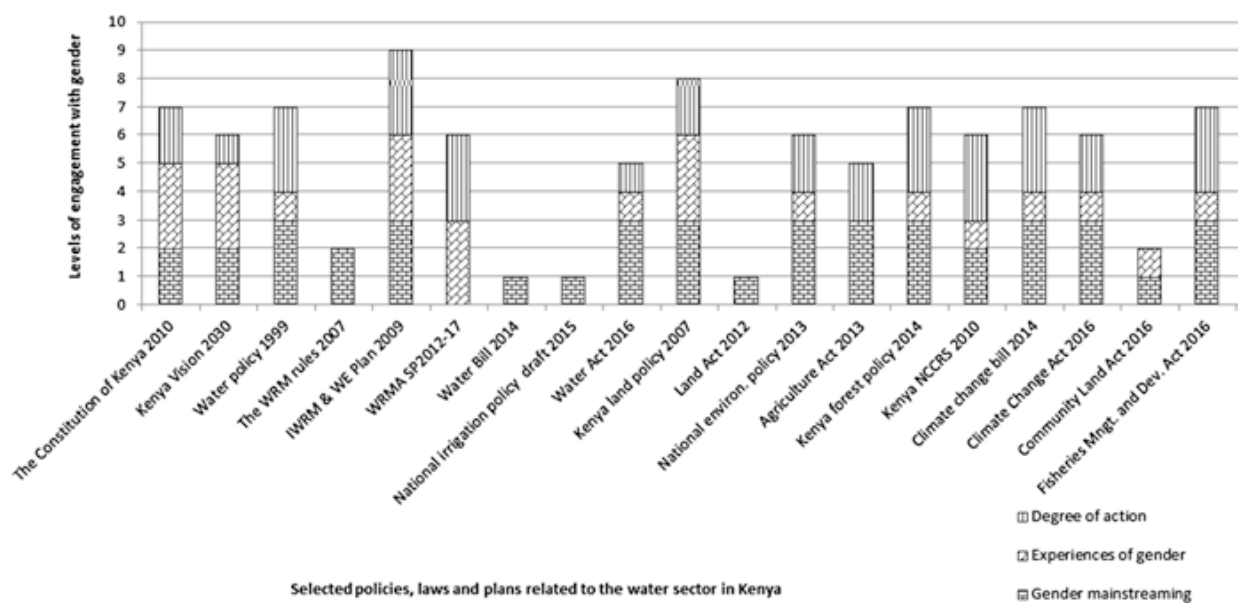

Fig. 7.2 Levels of engagement with gender equality in the three broad dimensions in water- and related policies and plans

\subsubsection{The General Gender Policy Framework in Kenya}

The Constitution of Kenya 2010 has institutionalised gender rights and gender equality. In Article 27(1) it states, "Every person is equal before the law and has the right to equal protection and equal benefit of the law." It specifies in Article 27 (3) that "women and men have the right to equal opportunities in political, economic, cultural and social spheres" (RoK 2010a, 24). It stipulates equitable access to land and elimination of gender discrimination (RoK 2010a, Art. 60; p. 42) and inscribes "values and principles of public service" whereby "adequate and equal opportunities" in employment in the public service should be given to both men and women (RoK 2010a, Art. 232, p. 139-140). In various Articles, the Kenya Constitution 2010 (27(8), 58(4); 81(b); 175(c); 177(1b); 197(1)) stipulates that not more than 
two thirds of the members of elective or appointive bodies of government at various levels shall be of the same gender (RoK 2010a). This has become popular as the "two thirds gender rule". Although not yet achieved in all cases, it has become a benchmark not only in Kenyan politics and public service but is also spreading to non-governmental processes.

From a government-wide perspective, the Constitution of Kenya 2010 (RoK 2010a) and the Kenya Vision 2030 (RoK 2007a) scored moderate to high (Kenya Constitution: 7/9; Vision 2030: 6/9) in their engagement with gender (Fig. 7.1) with the constitution addressing gender in 6 of the 8 sub-dimensions, namely, recognising the different needs and experiences of men and women, with objectives, actions and/or indicators that aim to reduce gender disparities (gender-sensitive). The constitution is also gender-responsive by making recommendations for equal participation of men and women and providing room for women to occupy two-thirds of any elective or appointed positions, which are currently dominated by men. Through equal rights in all spheres it promotes a rethinking of changes in social values relating to what women or men can be, do or have. It thus plans to coordinate and facilitate gender mainstreaming in national development (RoK 2010a, 40) and eliminate gender discrimination. Through making recommendations to reduce gender inequality and proposing concrete plans and timelines the Constitution of Kenya promotes a reduction of gender inequality.

The Kenya Vision 2030 already laid the groundwork, as many gender concerns it addresses were adopted in the constitution. The Kenya Vision 2030, which was developed before the 2010 Kenya Constitution, is Kenya's national long-term development plan that aims to transform Kenya into an industrialising, middle-income country (Republic of Kenya 2007a). The Vision 2030 recognises the disparities between Kenyan men and women, thus stipulating the equality of all Kenyan citizens, and increasing the participation of women in all economic, social and political decision making processes. It promotes a higher representation of women in parliament, institutionalising the Women Enterprise Fund, increasing the fund allocations and improving efficiency in the projects run by their beneficiaries as well as promoting equitable distribution of water (RoK 2007a).

Gender affairs in Kenya have undergone various organisational reforms from its rise to prominence since the Kenya National Policy on Gender and Development (NPGD), (RoK 2000), which aims "to facilitate the mainstreaming of the needs and concerns of men and women in all areas in the development process in the country" (RoK 2000), to its entrenchment in the Kenyan Constitution. These processes have culminated in the establishment of the National Gender and Equality Commission (NGEC) based on the NGEC Act of 2011 (RoK 2011) and the State Department of Gender Affairs (SDGA) as part of the Ministry of public service, youth and gender affairs in 2015. The NGEC Section 8(a) has among others the responsibility "to promote gender equality and freedom from discrimination in accordance with Article 27 of the Constitution" (RoK 2011, 7). The NGEC can investigate cases of gender discrimination and where necessary refer such cases to the relevant authorities for prosecution (RoK 2011). The SDGA created "to promote gender mainstreaming in national development processes and champion the socio-economic 
empowerment of women", is responsible for "expanding credit financing to women for enterprise development and ensuring equality in gender representation in all public appointments" (Republic of Kenya 2016b).

The SDGA also monitors compliance with international conventions and treaties that Kenya signed. Like many other African states, Kenya has committed itself in international conventions and agreements to address gender inequalities and take gender into account in national development. For Kenya, such agreements include the Convention on the Elimination of All Forms of Discrimination against Women (CEDAW; 1979), the World Conference on Human Rights (1993), the Fourth World Conference on Women in Beijing (1995) and the Beijing +5 (2000), the Millennium Development Goals (MDGs; 2000) and the Sustainable Development Goals (SDGs; 2014). In line with these commitments, the Government of Kenya (GoK) established various legal frameworks and institutional arrangements to ensure that gender is mainstreamed into all government activities.

Prior to the reorganisation into NGEC and SDGA, the former Kenya Ministry of Gender, Sports, Culture and Social Services (MGC\&SS) had various instruments to promote gender equality and women's empowerment. These included the 2006 Presidential Directive on Affirmative Action that stipulated a minimum of $30 \%$ women in recruitments, promotions and appointments in the public service (including all armed forces), the creation of gender focal desks in all ministries and parastatals as well as the Women Enterprise Fund (Ifejika Speranza 2010). These instruments reflected the political will of the Kenyan leadership to promote gender equality - the current dispensations on gender emphasise this political will. According to the MGC\&SS (2010), the appointment of gender officers resulted in gender mainstreaming becoming an indicator in the performance contracts for the public sector. MGC\&SS argued that this was a milestone for Kenya as organisations would ensure gender is mainstreamed in policy, planning, programming and budgeting in their sectors. Gender rights and gender equality thus have a strong institutional policy base in the Kenyan government. In the following we examine how other government policies, bills, acts and plans on the water and related sectors engage with gender.

\subsubsection{Engaging with Gender in the Water Sector}

The 1999 Water Policy (RoK 1999), which forms the basis for contemporary water governance in Kenya, addresses 7 out of the 8 gender dimensions examined. However, the Water Act 2002 (RoK 2002), which was only recently succeeded by the Water Act 2016, did not address gender at all while the Water Bill 2012, the Water Act 2016 (RoK 2016a) and the national irrigation policy draft 2015 (RoK 2015a), engage gender to the extent that they recognise the different needs and experiences of women and men related to water. The Water Bill 2012 reaches further in its aims to reduce gender disparities in access to water, and in recommending increased women participation in water governance. 
The low engagement in the Water Act 2002 and the Water Bill 2014 is compensated by the succeeding Water Act 2016 that scores medium in its engagement with gender (Figs. 7.1 and 7.2). The Water Act of 2016 explicitly draws on principles and values stipulated in the Kenyan constitution. These include equitable access to land, the elimination of gender discrimination, and ensuring equal opportunities for both men and women (cf. Republic of Kenya - RoK 2002, 2010a, 2016a).

High engagements with gender are found in the various strategic and other plans of the water sector (cf. RoK 2009a, 2013a). The Water Resources Management rules 2007 (RoK 2007b) only addresses gender sensitivity and responsiveness by stipulating that for the Kenyan Water Resources Management Authority (WRMA) to register Water Resources Users Associations (WRUAs), the WRUAs must have constitutions that among other things promote gender mainstreaming (Note that with the Water Act 2016, which repeals the Water Act 2002, the WRMA transforms into the planned Water Resources Authority: WRA). As the WRMA (to become the WRA) is in charge of water resources management in Kenya and is mandated to enforce rules, other actors in the water sector are likely to adopt at least the minimum conditions set by the WRMA on gender equality and women empowerment. Further, Kenya's Water Sector Strategic Plan 2010-2015 stipulates that at least 30\% of management committee members must be women (cf. RoK 2009a). It thus plans to develop and implement gender policy to guide mainstreaming, to sensitise its employees on gender, and to ensure compliance of one-third-gender representation in water governance and to collect sex disaggregated data. It also aims to engage women in the projects of the WRMA, with the goal of empowering them, and to develop and implement workplace policy on gender based violence. For all these activities, timelines have been set.

Finally, the Integrated Water Resources Management and Water Efficiency Plan for Kenya (IWRM and WEP; RoK 2009b) engages with gender in all its dimensions, aiming to mainstream gender, accounting for the practical and strategic needs of women and men and planning various actions (Fig. 7.1). While the water policy emphasises equity in access to water resources it does not explicitly mention gender dimensions of water resources management. The WRMA and IWRM-WEP stipulate stakeholder participation in water planning and management, in particular the participation of women, disadvantaged groups and the poor, and recognise that emphasis be given to capacity building and training of these social categories (cf. RoK 2009b). Hence we can conclude that the Kenya water sector is highly engaged in reducing gender inequality and promoting the representation and empowerment of women in water governance in Kenya. As the Ministry of water and irrigation with its departments and agencies are not the only government organisation working on water resources we expand our analysis to include other ministries focussing on environment and natural resources. 


\subsubsection{Engaging with Gender in Other Water-Related Sectors}

Water resources management and governance are intricately linked with land management and governance as governance measures affecting land also affect water access and management. As such we extend the analysis to include land policies, laws and regulations, and other policies related to the agriculture sector. While the Land Act 2012 (RoK 2012) only acknowledges gender, the underlying Kenya land policy 2007 (RoK 2007c) engages with gender at a high level, addressing gender issues in seven out of the eight gender sub-dimensions (Fig. 7.1) and in the three main dimensions (Fig. 7.2), stopping short of concrete actions to reduce gender inequality. While the Community Land Act 2016 (RoK 2016c) stipulates nondiscrimination and equality of gender it does not explicitly address gender with respect to customary law and customary land rights, considering that in many customary land rights, women's access to land is still dependent on their relationships with men (Ifejika Speranza 2006). The national environmental policy 2013 engages six out of the eight gender sub-dimensions (Fig. 7.1) and moderately addresses the three main gender dimensions (Fig. 7.2). It acknowledges the important role that gender plays in environmental management, the different ways gender mediates environmental impacts, hence proposes enhancing access to and ownership of resources for all gender (RoK 2013b).

The Agriculture, Fisheries and Food Authority Act 2013 (Agriculture Act 2013; RoK 2013c) moderately engages with gender but only in two dimensions, mainstreaming and recommending or implementing actions to reduce gender inequality that comprise five sub-dimensions (Fig. 7.1). It aims to "provide for mechanisms to ensure that not more than two thirds of elected members are of the same gender", and to provide women technical and other assistance with the aim of enhancing their socio-economic development. The Fisheries Management and Development Act 2016 (RoK 2016d) scores high and foresees further action to reduce gender inequality. Although the Forest Conservation and Management Act 2016 (RoK 2016e) draws on provisions made in the Kenya Constitution and foresees collaboration with community forest associations, unlike other Acts, it makes no reference to gender representation or to equity issues. The Kenya forest policy 2014 however, engages with gender at a high level, addressing the three gender dimensions (Fig. 7.2), comprising seven out of the eight gender sub-dimensions (Figs. 7.1 and 7.2) in the framework (Table 7.1). It aims to mainstream gender and "ensure gender equity in all" its "bodies at all levels, and to develop and implement a Gender and Forest Development Strategy" (RoK 2014b, 13). By aiming to "provide more opportunities and incentives for women to enter into forest training", education, careers and occupations, it acknowledges women's marginalised positions in forest use and management (RoK 2014b, 12). 


\subsubsection{Engaging with Gender in Climate Policy}

Although climate change is not a sector, its cross-cutting nature implies it is important to consider its intersections with gender and water. With climate variability and climate change advancing, ensuring that responses to climate change engage with gender is critical. Both the National Climate Change Response Strategy 2010 (NCCRS; RoK), and the Climate Change Bill 2014 (RoK 2014c) engage with gender at moderate levels, with the former covering the three dimensions and the latter covering only two dimensions. In detail both address six out of the eight subdimensions of gender engagement (Fig. 7.1). The NCCRS aims to adopt a "participatory approach that involves different water users including men and women's groups in water resource management" (p. 53). It advocates for gender-based response strategies such as making improved energy saving "stoves that are accessible and affordable to all families and individuals, particularly women; working with women groups and field-based gender officers in disseminating climate change information" and "ensuring and encouraging equal representation of men and women in technology development, training and transfer" (RoK 2010b, 86). Mainstreaming gender into climate change responses is also a goal of Kenya's Intended Nationally Determined Contribution (INDC) submitted to the United Nations Framework Convention on Climate Change (cf. RoK 2015b).

The Climate Change Bill 2014 aims to establish a National Climate Change Council among whose responsibilities will be to "coordinate gender-responsive public education and awareness programmes on climate change and facilitate gender-balanced public participation in climate change programmes at the national and county governments" (RoK 2014c, 7). The Climate Change Bill also stipulates that not more than two-thirds of the staff of the council shall be of the same gender. With these plans becoming law, the Climate Change Act 2016 scored 7 points in its engagement with gender, through aiming to mainstream gender equity in all climate change responses; complying with the "two-thirds gender principle" and setting procedures that ensure gender equity in access to climate funds (cf. RoK 2016f).

\subsubsection{Levels of Engagement with the Different Sub-dimensions of Gender}

To obtain an overview of the extent to which the various sub-dimensions of gender engagement are captured in the policies and plans of the government bodies, we summarised the instances into percentages (Fig. 7.3). By instances we mean the number of times (in percentage) that policies engage with a particular gender subdimension (Fig. 7.3).

Taken together, the sub-dimensions constituting the gender mainstreaming dimension, namely, gender-sensitivity (84\%), gender-responsiveness (74\%) and gender transformativeness $(63 \%)$, received the greatest attention in the policies and plans compared to the other dimensions (Fig. 7.3). 


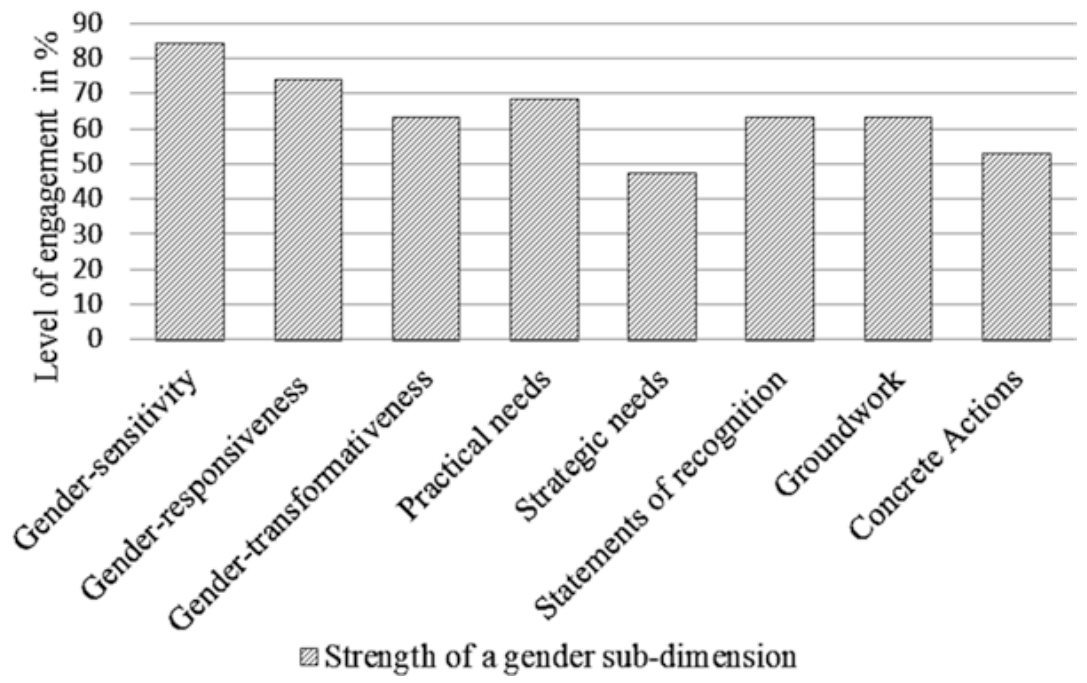

Fig. 7.3 The level of engagement of policies and plans with gender by sub-dimensions

With $68 \%$ and $47 \%$ respectively, the extent to which practical and strategic gender needs, that is the specific needs of different genders are acknowledged and addressed in the policies and plans, are relatively moderate to low. Further, the extent of action being taken to reduce gender inequality - that is, acknowledging that an unequal relationship exists that needs to be addressed (Statements of recognition 63\%), making recommendations that would reduce gender inequality (Groundwork 63\%), and describing concrete actions that have been taken or are being taken to reduce gender inequality (concrete actions 53\%) is also relatively moderate in the policies and plans (see Table 7.1 and Annex 7.1 for details).

\subsubsection{The Practice of Engaging with Gender in Community Water Projects}

In the following, we examine the engagement with gender in water practice by analysing how community water groups (CWGs) manage and use water. Characterised by a mostly semi-arid lowland, and a sub-humid and humid highland, access to water in the Mount Kenya region is often difficult for downstream users. Competition for water between various uses ranging from domestic activities to irrigation by foreignexchange earning commercial horticulture farms, further increases the strain on water resources and tensions about its use (Ifejika Speranza et al. 2016). CWGs, which are self-help groups, thus aim to improve their members' access to water. A major question that we ask in this section is whether CWGs manage and use water in ways that engage with gender. Using the same scheme in Table 7.1 we explore the extent to which CWGs engage with gender taking the case of community water projects in the Ewaso-Ngiro North Basin (ENNB) encompassing parts of the Mount Kenya region. 
Firstly, we describe the context of the community water projects. In many areas of the ENNB, public water supply is non-existent. Hence people have to selforganise to develop water infrastructure. In such cases, participation in the CWG depends on financial capabilities with gender having little or no influence on which households participate in the water projects. However, gender might gain prominence in the management of the CWG and in the access to and use of the water resources.

To access Kenya's water resources, a CWG has to become a member of a Water Resources User Association (WRUA) and register with the WRMA, which is the Kenyan agency responsible for water resources management. Through registration with WRMA, CWGs have to pay water fees to the WRMA according to the amount of water abstracted from rivers or streams (between KSH0.7 and KSH1 per cubic meter). The costs of registration with the WRMA as well as the costs of developing water infrastructure are paid by members of the CWG (e.g. each member of the Nyakairu CWG pays KSH1200 per year; ca. US\$12). Through these mechanisms, the CWGs become bound into the water governance framework of WRMA, and the WRUA, which is responsible for water management at a sub-catchment level. WRUAs formulate and implement the Sub-Catchment Management Plans. One of the stipulations by WRMA is the $30 \%$ women representation in the WRUAs. This stipulation has trickled down to about $90 \%$ of the CWGs that have women represented in their management committees.

It is important to note that local men and women developed most of the CWGs as a basis for improving their access to water through developing water infrastructure. The different needs and experiences of gender were only recognised in cases where women were represented in the Project Management Committees (PMC). As government resources are inadequate to provide water infrastructure, men and women organised themselves into groups to take advantage of the water governance arrangements by the WRMA, which stipulates that for inhabitants to develop water infrastructure and be eligible for registration by WRMA, they have to form groups. Through social norms regarding gender roles and responsibilities, women in the study area, like in many Kenyan contexts, are responsible for providing their households with water for domestic use. Where water is not available in the home they have to walk to the rivers or to the water points to fetch water, spending hours that could be spent on other livelihood activities. In many contexts, men strive to improve their access to water also for agricultural production through irrigation. Thus where men and women's access to water is inadequate, both men and women strive to improve access to water for both reproductive and productive purposes as is the case of the CWGs in Laikipia. However, acquiring group membership is only through cash or in-kind labour contributions at household level. Thus wealth determines whether a household (male-headed, female-headed or female managed) can afford the contributions to participate in such CWGs.

While gender may not be a differentiating phenomenon for group membership, it does play a role in the management of the CWGs. Each CWG has a project management committee that comprises in most cases a chairperson, secretary, treasurer, vice-chair-person and vice-secretary in order of prevalence. Women were repre- 
sented in 90\% (27) of the PMCs of the 30 water projects. Taken together the proportion of women in the 27 PMCs was $30 \%$ while men occupied $70 \%$ of the positions. Although only one project has a youth representative and a women's group representative, in 33\% (10) of the projects, a sub-committee is in charge of ensuring gender representation in the CWG activities. The sub-committees ensure attention to issues that are important to the CWGs and compliance with institutional arrangements in which the CWGs are embedded, among them, government policies and norms. Thus gender mainstreaming in such CWGs reflects an explicit attempt to integrate women into the decision-making processes of the CWGs. In those 10 projects, the PMC-respondents regard women representation in the organizational structures of the projects as having influenced project outcomes. Statements by the respondents reflect this approach: Different genders/age groups reach out to others in the community of the same age/gender over the project (Men, women, youth); Gender issues are considered and all genders are represented; Women are the ones that know the water problems.

However, such statements also reflect the perceptions that members have of women's roles:

The treasurer is female, as we believe women are better at handling money.

The roles assigned to women reflect certain expectations as women are assigned stereotype roles: The community recommends that the chairperson and treasurer be women as they understand water problems the most and commit to success of the project; The distribution of roles are defined (men- guard water project, women-use) fetch water; youth do maintenance work). While such an approach helps to address the practical needs of gender and the different age categories, an explicit reevaluation of power distribution does not exist as women are assigned roles based on the perceived stereotypes that they embody.

We analysed whether women in terms of female-headed households or wives receive fewer benefits than male project members. We found no significant difference in access to water and other benefits of group membership between the men and the women. Results show that more women (58\%) use water for domestic purposes compared to men (39\%), while for livestock more women (47\%) also use the water than men (33\%). $11 \%$ of both men and women use the water for irrigation.

Apart from the stereotype roles in the PMCs, there is no difference between the roles of men, women and youth members in the water projects. All three categories had to contribute their labour to the water projects (men $75 \%$; women $72 \%$; youthgenerally above 18 years: $75 \%$ ). A similar proportion of men, women and youths (men 26\%, women $24 \%$ and youths $25 \%$ ) contributed to constructing project infrastructure such as the water intake, pump/electricity house, or storage tank and fixing/connecting/installing pipes and taps. Men, women and youth also plant trees, live fences or grass in comparable number of projects.

The nature of the projects played an important role in determining if both men and women as members of a project played active roles or not. For instance, in a project that was completely developed by external actors, members could access the water for free and were also not expected to take on any active roles. 
For all respondent categories the main reason for positive change brought by the water projects was because they reduced the time (49\%) and distance to water (70\%), provided irrigation water (19\%), which increased food production and incomes, reduced labour and financial costs of accessing water (19\%) and stabilised or increased livestock production $(21 \%)$ as well as improved health and sanitation conditions in the communities.

The water projects improved the ability of men and women to interact with different types of people, their ability to seek ideas, skills and knowledge from others, and in that sense built social capital. Through farming and sales of horticultural and farm produce, many projects generate income and food for member households. Project dividends are shared in some projects while in others development projects were started with saved time and money, and created employment. In certain cases the projects led to increases in land prices (as water became available), reduction of expenses in cost of living and reduced conflicts over water.

Where social conditions were conducive, people helped one another and shared the same resources. Connected by common challenges they collectively sought ways of starting a water project. However negative issues arose when it came to borrowing water as members were not allowed to give non-members water, thus creating tensions between non-members and members.

Respondents often reported the CWGs triggered the formation of women groups. In no instance was the formation of men groups reported. We interpret that the CWG offered women a platform to self-organise. While the statements of some of the respondents hint at existing power gradients between men and women and the CWGs acknowledge the importance of ensuring adequate representation of women in the project management and its activities, explicit actions to address strategic gender interests such as aspiring for gender equality could not be identified. Rather, it seems that the CWGs are adjusting to the prevailing norm of $30 \%$ women representation. Strategic needs are then addressed indirectly through the platform that the CWGs provide women to form women groups. Besides water issues, the group members were engaged in other networks such as self-help groups involving women ( $13 \%$ - 43 women), or men (only 1 case). About $53 \%$ of the members established groups on various activities ranging from business, buying land to share among members, farming activities, tree planting to community security.

Gender inequality was not perceived as a social challenge by most respondents with only one respondent mentioning gender biases as a challenge, that "in some communities, it is culture that women have more roles than men", and that "failure to attend community meetings remains a challenge", as "people still stick to traditions, especially women, and do not want to attend meetings”. It was also mentioned that "women groups do not thrive or often fail". Despite these insights the water projects generally improved the living standards of its members: due to the improved access to water, women in the project have more time to do other activities which did not reduce work burdens as such but enabled men and women to engage in other social and economic activities (e.g. bee keeping, women-group activities, and increased farm activities). Based on the foregoing, we assess the engagement of the CWGs with gender to be in general high, scoring 7 out of 9 points (Table 7.2). 
Table 7.2 Gender Engagement Framework - examining the level to which community water projects engaged with gender

\begin{tabular}{l|l}
\hline Attributes and dimensions of engagement & $\begin{array}{l}\text { Scoring system } \\
\text { (Yes:1; No:0) }\end{array}$ \\
\hline $\begin{array}{l}\text { 1. Gender mainstreaming: extent to which gender concepts are being } \\
\text { applied in the CWGs }\end{array}$ & $\begin{array}{l}\text { Total possible } \\
\text { score: } 3\end{array}$ \\
\hline (i) Gender-sensitivity & $1 / 1$ \\
\hline (ii) Gender-responsiveness & $1 / 1$ \\
\hline (iii) Gender-transformativeness & $0 / 1$ \\
\hline $\begin{array}{l}\text { 2. Experience of gender: extent to which the specific needs of different } \\
\text { genders are acknowledged and addressed in the CWGs }\end{array}$ & $\begin{array}{l}\text { Total possible } \\
\text { score: } 3\end{array}$ \\
\hline (iv) Practical needs & $1 / 1$ \\
\hline (v) Strategic needs & $1 / 2$ \\
\hline 3. Degree of action: extent of action being taken to reduce gender & $\begin{array}{l}\text { Total possible } \\
\text { inequality in the CWGs }\end{array}$ \\
\hline (vi) Statements of recognition 3
\end{tabular}

Adapted from Bunce and Ford (2015)

Source: Authors' Analysis

The results in Table 7.2 are generally similar to the results from the assessment of government policies - while an overall score of 7 points is high, the degree of transformative action to reduce gender inequality and address strategic gender needs remains generally low to moderate.

\subsection{Discussion}

To examine the extent that Kenya government bodies working on water and related environmental issues engage with gender, we adapted and applied the gender engagement framework of Bunce and Ford (2015). Through an empirical study, we also analysed how community water groups engage with gender. This framework has provided useful insights on the extent to which gender equality is addressed, both in policy and practice, thus capturing a top-down notion and a bottom-up experience of gender engagement (cf. Warren 2007).

Our findings show that most policies and plans of the Kenyan government generally engage with gender as a top-down structural measure. Gender rights, equality and equity thus have a strong policy and regulatory base in the Constitution of Kenya 2010 and the Vision 2030. These policies have had multiplier effects across the spectrum of development to stimulate sustainable resource management, greater productivity and resilience (cf. AHDR 2016, 1-9; cf. FAO 2011). Although achieve- 
ments are gradual and the transition is slow, they have set a benchmark not only in Kenyan public policy but also in the water and environment sectors.

The gender mainstreaming approach adopted at national levels by government organisations is not a matter of choice but more of an obligation required by the Kenyan constitution and stipulated in the public service. This stipulation cascades to government ministries and parastatals under their authority. As Alston (2009) argues, gender mainstreaming is thus critically dependent on high-level government support for reducing gender inequality and when such support is inexistent, changing intransigent culture remains even more difficult.

Although a "one-half" approach might align better with gender equality, the "30\%" or the "two- thirds" obligation by the Kenyan government is transformative in that it changes existing systemic structures that have to make place for women, thus displacing the men that were previously occupying such positions prior to the regulations. In that sense, the gender mainstreaming has become a benchmark, setting the agenda in the governance structure of Kenyan government activities and in its relations with the civic and private sectors. In the case of the CWGs we analysed, women are starting to occupy such space.

While Kenya has introduced an array of policy documents and strategic plans directly and indirectly related to promoting gender equality in the water and related sectors, the challenge is fine-tuning the various policies and ensuring standards are advocated, accepted, fully implemented and enforced (cf. AHDR 2016, 1-9). The situation is compounded by the gap between legal rights, expectations and prevailing practices and behaviours embodied in social and cultural norms. Thus, the amount of resources the Kenya government makes available to reduce gender inequality and how effectively they are used can be used as an indicator of government's commitment to reduce gender inequality.

There has to a certain extent been a trickle-down effect on measures to reduce gender inequality from the national to the local levels. While the CWGs are essentially a bottom-up response strategy to inadequate water supply, they too have had to adopt government stipulations on gender representation as a precondition to become registered by WRMA. However, achieving strategic gender needs remains a challenge. Actions to address strategic gender needs, such as aspiring for gender equality was not an explicit focus of the CWGs. Strategic needs are then addressed indirectly through the platform that the CWGs provide women to form women groups. Moreover, the CWG activities aimed to ensure equality of costs and benefits in accessing project water but financial capability seem to be the more determinant factor of participation than gender.

An additional finding beyond our research questions is that project activities have led to an increase in economic activities that support livelihoods e.g. horticulture and sale of farm produce, generating income and food for member households. Activities of the CWGs have also provided avenues of building social capital exploited more by women than men. There is thus a need to further explore the role of financial capability as well as social networks in determining access to water.

Furthermore, results hint at the limits to gender mainstreaming, which highlights it as one in a portfolio of methods and strategies to achieve gender equality in water 
use and management. As gender, is about relations and expectations between men and women, embedded in their socio-cultural belief systems and norms, mainstreaming is inadequate to completely reduce gender inequality and even more so in the short-term (Smyth 2010; Bock 2015). Complementary activities that influence socio-cultural belief systems and norms towards a more gender-equitable society such as long-term persistent socioeconomic change and individual resistance (Ridgeway and Correll 2004; Quisumbing et al. 2014) are thus needed to enhance the progress made through mainstreaming.

Finally, our assessment scheme is likely limited in capturing the full range of ways through which gender inequality is exercised and addressed. Yet having a more comprehensive set of indicators might not shed more light on the subtleties of gender inequality especially when paired with financial capacity. While our data did not capture the perspectives of those members of the community that are excluded from the CWGs, the fact that financial capacity is key to participating in CWGs calls for an intersectionality lens. Exploring those excluded in terms of their gender and financial capacity could shed light on the roles of intersecting social categories in exclusion from water projects. This research gap needs to be addressed in future studies.

\subsection{Conclusion}

This article sought to address three objectives: (1) to examine the levels to which water-related policies and plans of the Kenyan government engage with gender, (2) to analyse how the framing conditions set by the policy and plans affect the management of community water groups and (3) to assess whether the community water groups through their activities reduce gender inequality in access to water and in decision making about water. We analysed Kenyan government policies and strategic plans related to the water and agriculture sectors as well as how community water groups engage with gender and translate government policies into practice at the community level. We found that gender mainstreaming in the Kenyan government policy and practice is advancing with stipulations on gender representation and empowerment of women enshrined in the Kenyan Constitution and various policy documents. The Kenya Water Resources Management Authority, the major government organisation in charge of water management, translates such regulations into practice through making a gender representation of $30 \%$ a pre-condition for community water groups to access water resources in Kenya. This stipulation of a $30 \%$ gender representation needs to be progressively increased. On their part, the CWGs engage with gender by ensuring women's access to decision making through their representation in $90 \%$ of the project management committees, although only $33 \%$ had a sub-committee on gender. Further, the CWGs mainly address practical gender needs while strategic gender needs are not explicitly addressed. At the most, the CWGs offer both men and women a platform to empower themselves through increasing collective action to improve their livelihood conditions, which otherwise would have been difficult to meet. We find that within the projects, gender plays out 
in the stereotype images that men have of women and vice versa, thus forming an invisible barrier to adopting other roles or enhancing gender equality. Thus, the CWGs have not managed to significantly change the underlying stereotypes or gender ideologies in the sense of assigning men and women certain roles but may have reinforced the stereotypes by institutionalising them through management positions e.g. treasures position which are also very difficult jobs. Further, while we used gender as an analytical lens in the CWGs, emerging insights hint at the need for further research on the intersection of gender with wealth in determining who attains project membership and by extension, access to water resources.

Acknowledgements The authors are grateful to the Volkswagen Foundation for funding this study in the framework of the research project on 'Semi-Arid Areas in Transition' under the programme 'Knowledge for Tomorrow - Cooperative Research Projects in Sub-Saharan Africa' [grant number I/83732]. We would also like to thank CETRAD staff for the support and logistics, especially during data collection. We thank Roger Cremades, Timothy Adams and the two anonymous reviewers for their helpful comments and suggestions.

\section{Annex 7.1 Results from the Analysis of Kenya Government Policies, Acts, Bills and Plans}

\begin{tabular}{|c|c|c|c|c|c|}
\hline \multirow[b]{2}{*}{ No. } & \multirow[b]{2}{*}{$\begin{array}{l}\text { Kenya government policies } \\
\text { and plans }\end{array}$} & \multicolumn{4}{|c|}{$\begin{array}{l}\text { Scores on engaging } \\
\text { with gender }\end{array}$} \\
\hline & & $\begin{array}{l}\text { Gender } \\
\text { mainstreaming }\end{array}$ & $\begin{array}{l}\text { Experiences of } \\
\text { gender }\end{array}$ & $\begin{array}{l}\text { Degree } \\
\text { of action }\end{array}$ & $\begin{array}{l}\text { Total } \\
\text { Score }\end{array}$ \\
\hline 1 & $\begin{array}{l}\text { The Constitution of Kenya } \\
\text { (2010) }\end{array}$ & 2 & 3 & 2 & 7 \\
\hline 2 & Kenya Vision (2030) & 2 & 3 & 1 & 6 \\
\hline 3 & Water policy (1999) & 3 & 1 & 3 & 7 \\
\hline 4 & $\begin{array}{l}\text { The Water Resources } \\
\text { Management (WRM) rules } \\
\text { (2007) }\end{array}$ & 2 & 0 & 0 & 6 \\
\hline 5 & IWRM \& WE Plan (2009) & 3 & 3 & 3 & 9 \\
\hline 6 & WRMA SP(2012-17) & 0 & 3 & 3 & 6 \\
\hline 7 & Water Bill (2014) & 1 & 0 & 0 & 1 \\
\hline 8 & $\begin{array}{l}\text { National irrigation policy } \\
\text { draft (2015) }\end{array}$ & 1 & 0 & 0 & 1 \\
\hline 9 & Water Act (2016) & 3 & 1 & 1 & 5 \\
\hline 10 & Kenya land policy (2007) & 3 & 3 & 2 & 8 \\
\hline 11 & Land Act (2012) & 1 & 0 & 0 & 1 \\
\hline 12 & $\begin{array}{l}\text { National environ. policy } \\
\text { (2013) }\end{array}$ & 3 & 1 & 2 & 6 \\
\hline 13 & Agriculture Act (2013) & 3 & 0 & 2 & 5 \\
\hline 14 & Kenya forest policy (2014) & 3 & 1 & 3 & 7 \\
\hline 15 & Kenya NCCRS (2010) & 2 & 1 & 3 & 6 \\
\hline
\end{tabular}


Annex 7.1 (continued)

\begin{tabular}{|c|c|c|c|c|c|}
\hline \multirow[b]{2}{*}{ No. } & \multirow[b]{2}{*}{$\begin{array}{l}\text { Kenya government policies } \\
\text { and plans }\end{array}$} & \multicolumn{4}{|c|}{$\begin{array}{l}\text { Scores on engaging } \\
\text { with gender }\end{array}$} \\
\hline & & $\begin{array}{l}\text { Gender } \\
\text { mainstreaming }\end{array}$ & $\begin{array}{l}\text { Experiences of } \\
\text { gender }\end{array}$ & $\begin{array}{l}\text { Degree } \\
\text { of action }\end{array}$ & $\begin{array}{l}\text { Total } \\
\text { Score }\end{array}$ \\
\hline 16 & Climate change bill (2014) & 3 & 0 & 3 & 6 \\
\hline 17 & Climate Change Act (2016) & 3 & 1 & 2 & 6 \\
\hline 18 & $\begin{array}{l}\text { Community Land Act } \\
\text { (2016) }\end{array}$ & 1 & 1 & 0 & 2 \\
\hline 19 & $\begin{array}{l}\text { Fisheries Mngt. and Dev. } \\
\text { Act (2016) }\end{array}$ & 3 & 1 & 3 & 7 \\
\hline
\end{tabular}

High: 7-9 points; Moderate: 4-6 points; Low 0-3 points

\section{Bibliography}

AHDR (African Human Development Report) (2016). Accelerating gender equality and women's empowerment in Africa. United Nations Development Program (UNDP), 1-9

Alston M (2009) Drought policy in Australia; gender mainstreaming or gender blindness. Gender Place Culture 16(2):139-154. doi:10.1080/09663690902795738

Bikketi E, Ifejika SC, Bieri S, Haller T, Wiesmann U (2016) Gendered division of labour and feminisation of responsibilities in Kenya: implications for development interventions. Gender Place Culture:1-17. doi:10.1080/0966369X.2016.1204996

Bock B (2015) Gender mainstreaming and rural development policy; the trivialisation of rural gender issues. Gender Place Culture 22(5):731-745

Boserup E (1970) Woman's role in economic development. George Allen \& Unwin, London

Bryceson DF (1999). Sub-Saharan Africa betwixt and between: rural livelihood practices and policies. ASC working paper 43 / 1999. http://www.ascleiden.nl/pdf/wp43.pdf. Accessed 21 Aug 2016

Bunce A, Ford J (2015) How is adaptation, resilience, and vulnerability research engaging with gender? Environ Res Lett 10(2015):123003. doi:10.1088/1748-9326/10/12/123003

Butler J (1990) Gender trouble: feminism and the subversion of identity. Routledge, Chapman \& Hall, New York

Daley E (2011) Gendered impacts of commercial pressures on land. http://www.landcoalition. org/sites/default/files/documents/resources/MOKORO_Gender_web_11.03.11.pdf. Accessed 21 Aug 2016

Dancer H, Tsikata D (2015) Researching land and commercial agriculture in sub-Saharan Africa with a gender perspective: concepts, issues and methods,FAC working paper 132. Future Agricultures Consortium, Brighton. https://opendocs.ids.ac.uk/opendocs/bitstream/handle/123456789/7138/FAC_Working_Paper_132.pdf?sequence=1\&isAllowed=y. Accessed 21 Aug 2016

Doss RC, Kieran C (2015) The standards for collecting sex-disaggregated data for gender analysis: a guide for CGIAR researchers. Research program on policies, institutions and markets. http:// www.pim.cgiar.org. Accessed 21 Aug 2016

Doss C, Truong M, Nabanoga G, Namaalwa J (2012) Women, marriage, and asset inheritance in Uganda. Dev Policy Rev 30(5):597-616. doi:10.1111/j.1467-7679.2012.00590.x

Elson D (1995) Male bias in the development process. Manchester University Press, New York

Farnworth C, Fones Sundell M, Nzioki A, Shivutse V, Davis M (2013) Transforming gender relations in agriculture in Sub-Saharan Africa https://www.sei-international.org/mediamanager/ documents/Publications/SIANI-Gender-Africa-book/SIANI-2013-Transforming-GenderRelations-Agriculture-Africa.pdf. Accessed 21 Aug 2016 
Food and Agriculture Organisation of the United Nations (FAO) (2011) The state of food and agriculture: women in agriculture, closing the gender gap for development. FAO, Rome

Gallois S, Duda R, Hewlett B, Reyes-García V (2015) Children's daily activities and knowledge acquisition: a case study among the Baka from southeastern Cameroon. J Ethnobiol Ethnomed 11(86):1-13. doi:10.1186/s13002-015-0072-9

Ifejika Speranza C (2006) Gender based analysis of vulnerability to drought among agro-pastoral households in semi-arid Makueni District, Kenya. In: Premchander S, Müller C (eds) Gender and sustainable development: case studies from NCCR north-south, Perspectives of the Swiss National Centre of competence in research (NCCR) north-south, University of Bern, Vol.2. Geographica Bernensia, Berne, pp 119-146

Ifejika Speranza C (2010) Promoting gender equality in response to climate change; the case of Kenya, Studies/discussion paper. German Development Institute, DIE (Deutsches Institute fur Entwicklungspotitik), Bonn, pp 18-30. https://www.die-gdi.de/uploads/media/DP_5.2011.pdf. Accessed 2 May 2017

Ifejika Speranza C, Kiteme B, Wiesmann U, Jörin J (2016) Community-based water development projects, their effectiveness, and options for improvement: lessons from Laikipia, Kenya. Afr Geogr Rev. doi:10.1080/19376812.2016.1253485

Kabeer N (2010) Women's empowerment, development interventions and the management of information flows, vol 41. Institute of Development Studies Bulletin. Blackwell Publishing, Oxford, pp 105-112

Kassie M, Ndiritu WS, Stage J (2014) What determines gender inequality in household food security in Kenya/application of exogenous switching treatment regression. World Dev 56:153171. doi:10.1016/j.worlddev.2013.10.025

Kim S (2001) Hegemony and cultural resistance. Int Enc Soc Behav Sci, 2nd edn, 10:742-746. doi:10.1016/B0-08-043076-7/04332-1

Lastarria-Cornhiel S, Behrman JA, Meinzen-Dick R, Quisumbing AR (2014) Gender equity and land: toward secure and effective access for rural women. In: Quisumbing AR et al (eds) Gender in agriculture: closing the knowledge gap. Springer, Dordrecht, pp 117-144. doi:10.1007/978-94-017-8616-4_7

Lears TJJ (1985) The concept of cultural hegemony: problems and possibilities. Am Hist Rev 90(3):567-593. doi:10.2307/1860957

Mackenzie F (1990) Gender and land rights in Murang'a district, Kenya. J Peasant Stud 17(4):609_ 643. doi:10.1080/03066159008438437

MGC\&SD (Ministry of Gender, Children and Social Development) (2010) Gender and development. http://www.gender.go.ke/index.php/Genderand-Social-Development-Divisions/genderand-development.html. Accessed 23 Oct 2009

Mutugi MW (2006) The self-help group - ideal vehicle for gender education. In: Creighton C, Yieke F (eds) Gender inequalities in Kenya. UNESCO, Paris, pp 81-88, http://ku.ac.ke/schools/ education/images/stories/research/Gender\%20Inequalities\%20in\%20Kenya.pdf\#page $=87$. Accessed 21 Aug 2016

Quisumbing A (1996) Male-female differences in agricultural productivity: methodological issues and empirical evidence. World Dev 24(10):1579-1595. doi:10.1016/0305-750X(96)00059-9

Quisumbing AR, Meinzen-Dick R, Raney TL, Croppenstedt A, Behrman JA, Peterman A (2014) Closing the knowledge gap on gender in agriculture. In: Quisumbing AR et al (eds) Gender in agriculture: closing the knowledge gap. doi:10.1007/978-94-017-8616-4_1

Rao S (2016) Indicators of gendered control over agricultural resources: A guide for agricultural policy and research. Working paper, CGIAR Gender and Agriculture Research Network. https://cgspace.cgiar.org/bitstream/handle/10568/75779/Indicators $\% 20$ of $\% 20$ gendered $\% 20$ control\%20over\%20agricultural\%20resources_Workingpaper1.pdf?sequence $=5$. Accessed 21 Aug 2016

Rao N (2017) Assets, agency and legitimacy: towards a relational understanding of gender equality policy and practice. World Dev 95:43-54. doi:10.1016/j.worlddev.2017.02.018

Republic of Kenya (1999) Sessional paper No. 1 of 1999 on national policy on water resources management and development. Nairobi

Republic of Kenya (2000) National gender and development policy. Nairobi 
Republic of Kenya (2002) The Kenya Water Act 2002. http://www.water.go.ke/index. php?option=com_docman\&Itemid=89. Accessed 3 Jan 2014

Republic of Kenya (2007a) Kenya Vision 2030 popular version. Nairobi

Republic of Kenya (2007b) The water resources management rules 2007. http://kenyalaw.org/kl/ index.php?id=655. Accessed 21 Aug 2016

Republic of Kenya (2007c) National land policy 2007. Ministry of Lands, Kenya. Nairobi

Republic of Kenya (2009a) Kenya's water sector strategic plan 2010-2015. Nairobi

Republic of Kenya (2009b) WRMA integrated water resources management and water efficiency plan for Kenya. Nairobi

Republic of Kenya (2010a) The constitution of Kenya 2010. http://www.kenyalaw.org:8181/exist/ kenyalex/actview.xql?actid=Const 2010

Republic of Kenya (2010b) National climate change response strategy. Nairobi

Republic of Kenya (2011) The National Gender and Equality Commission Act, 2011. http://www. ngeckenyaorg/Downloads/The_National_Gender_and_Equality_Act_2011pdf. Accessed 21 Aug 2016

Republic of Kenya (2012) Land Act No 6 of 2012. National Council for Law Reporting. http:// www.kenyalaw.org/kl/fileadmin/pdfdownloads/Acts/Land_Act No_6_of_2012 1_.pdf. Accessed 21 Aug 2016

Republic of Kenya (2013a) Water resources management authority. strategic plan for 2012-2017. Nairobi

Republic of Kenya (2013b) National Environment Policy 2013. http://www.environment.go.ke/ wp-content/uploads/2014/01/NATIONAL-ENVIRONMENT-POLICY-20131.pdf. Accessed 21 Aug 2016

Republic of Kenya (2013c) Agriculture, Fisheries and Food Authority Act. No. 13 of 2013. Nairobi

Republic of Kenya (2014a) The Water Bill 2014. National Council for Law Reporting Library. Nairobi

Republic of Kenya (2014b) Forest policy 2014. Ministry of Environment, forest and natural resources. Nairobi

Republic of Kenya (2014c) The climate change bill 2014. http://kenyalaw.org/kl/fileadmin/pdfdownloads/bills/2014/ClimateChangeBill2014.pdf

Republic of Kenya (2015a) National Irrigation Policy 2015. http://wwwkilimogoke/wp- content/ uploads/2015/06/National-Irrigation-Policy-draft.pdf. Accessed 3 Dec 2016

Republic of Kenya (2015b) Kenya's Intended Nationally Determined Contribution (INDC). 23 July 2015. http://www4.unfccc.int/submissions/INDC/Published\%20Documents/Kenya/1/ Kenya_INDC_20150723.pdf

Republic of Kenya (2016a) The Water Act 2016. http://kenyalaw.org/kl/fileadmin/pdfdownloads/ Acts/WaterAct_No43of2016.pdf. Accessed 26 Nov 2016

Republic of Kenya (2016b) About State Department of Gender Affairs. http://www.psyg. go.ke/2016-02-05-06-32-50/gender-affairs-pr.html. Accessed 21 Aug 2016

Republic of Kenya (2016c) Community Land Act 2016. http://kenyalaw.org/kl/fileadmin/pdfdownloads/Acts/CommunityLandAct_27of2016.pdf. Accessed 26 Nov 2016

Republic of Kenya (2016d) The Fisheries Management and Development Act 2016. http://kenyalaw.org/k1/fileadmin/pdfdownloads/Acts/FisheriesManagementandDevelopmentAct_N. o35of2016.pdf Accessed 26 Nov 2016

Republic of Kenya (2016e) The Forest Conservation and Management Act 2016. http://kenyalaw. $\mathrm{org} / \mathrm{kl} /$ fileadmin/pdfdownloads/Acts/ForestConservationandManagementActNo34of2016.pdf. Accessed 26 Nov 2016

Republic of Kenya (2016f) Climate Change Act 2016. http://kenyalaworg/kl/fileadmin/pdfdownloads/Acts/ClimateChangeActNo11 of2016pdf. Accessed 26 Nov 2016

Ridgeway CL, Correll SJ (2004) Unpacking the gender system: a theoretical perspective on gender beliefs and social relations. Gend Soc 18:510-531. doi:10.1177/0891243204265269

Schlager E, Ostrom E (1992) Property-rights regimes and natural resources: a conceptual analysis. Land Econ 68(3):249-262. doi:10.2307/3146375 
Smyth I (2010) Talking of gender: words and meanings in development organisations. In: Cornwall A, Eade D (eds) Deconstructing development discourse: buzzwords and fuzzwords. Practical Action Publishing and Oxfam, Oxford, pp 144-151

SOFA - The State of Food and Agriculture Team, Doss C (2011) The role of women in agriculture, ESA working paper no. 11-02. The Food and Agriculture Organization of the United Nations, Agriculture Development Economics Division, Rome. http://www.fao.org/docrep/013/ am307e/am307e00.pdf. Accessed 21 Aug 2016

Tinker, I. (1990). The human economy of micro-entrepreneurs. Paper presented at the International Seminar on Women in Micro and Small-scale Enterprise Development. Ottawa, Ontario, Canada

Tsikata D, Yaro JA (2014) When a good business model is not enough: land transactions and gendered livelihood prospects in rural Ghana. J Fem Econ 20(1):202-226. doi:10.1080/1354570 1.2013 .866261

UN (United Nations) (1997) Report of the fourth world conference on women, Beijing, 4-15 September 1997 (United Nations publication, Sales No. E.96.IV.13), Chap. I, Resolution 1, Annex II. http://www.un.org/womenwatch/daw/followup/main.htm. Accessed: 02 May 2017

USAID (2014). Kenya-water and sanitation profile http://pdf.usaid.gov/pdf_docs/Pnado931.pdf. Accessed 11 Nov 2016

Warren H (2007) Using gender-analysis frameworks: theoretical and practical reflections. Gend Dev 15(2):187-198. doi:10.1080/13552070701391847

World Development Report (WDR) (2012) Gender equality and development. The International Bank for reconstruction and development/The World Bank, Washington, DC, pp 72-91

Wyrod R (2008) Between women's rights and men's authority: masculinity and shifting discourses of gender difference in urban Uganda. J Gend Soc 22(6):799-823. doi: $10.1177 / 0891243208325888$ 